\title{
PENGARUH STRES POST PARTUM TERHADAP PEMBENGKAKAN PAYUDARA PADA IBU MENYUSUI DI DESA MATANAIR
}

\author{
Sri Yunita Suraida Salat, Program Studi Diploma Kebidanan Universitas Wiraraja \\ e-mail : yunitafik@wiraraja.ac.id \\ Ratna Indriyani, Program Studi Diploma Kebidanan Universitas Wiraraja \\ e-mail : ratnaindriyani@wiraraja.ac.id
}

\begin{abstract}
ABSTRAK
Pembengkakan payudara dalam masa post partum merupakan kondisi dimana payudara membengkak yang disebabkan karena jumlah ASI yang berlebihan di dalam payudara. Biasanya hal ini disertai rasa nyeri. Pembengkakan payudara ini bisa terjadi di pada sebagian payudara atau seluruh payudara. Awalnya setiap ibu post partum menganggap kejadian pembengkakan payudara ini merupakan hal yang biasa dialami oleh ibu menyusui. Bahkan ada beberapa daerah di wilayah Sumenep yang menghubungkan kejadian pembengkakan payudara ini dengan "MITOS" budaya setempat. Ada bebebrapa faktor yang dapat menyebabkan terjadinya pembengkakan payudara dan salah satunya adalah cemas atau stress yang dirasakan ibu post pastum. Tujuan Penelitian ini Menganalisis Pengaruh Stres Post Partum Terhadap Pembengkakan Payudara Pada Ibu Menyusui Di Desa Matanair.

Penelitian ini termasuk dalam jenis penelitian analitik yang menggunakan metode cross sectional. Populasi yang digunakan adalah Semua ibu yang sedang menyusui di Wilayah Kerja Polindes Desa Matanaair Kecamatan Rubaru Kabupaten Sumenep pada Bulan Januari - Februari 2019 sebanyak 18 ibu menyusui. Besar sampel penelitian adalah 18 orang dengan teknik sampel total sampling. Variabel penelitian dalam penelitian ini yaitu : stress post partum, pembengkakan payudara. Pengumpulan data menggunakan lembar kuisioner DASS 42 dan Cheklist. Data akan dianalisis menggunakan uji korelasi spearman.

Hasil penelitian menunjukkan bahwa 3 orang yang tidak mengalami stress seluruhnya hanya mengamali pembengkakan ringan yaitu 100\%, dan dari 7 orang ibu yang mengalami stres sedang dalam masa nifas sebagian besar mengalami pembengkakan payudara yang berat yaitu 60\%. Sedangkan dari 8 Orang ibu yang mengalai stress parah pada masa nifas sebagian besarmengalami pembengkakan payudara yang berat yaitu 57\%. Dan 1 orang ibu yag mengalami stress sangat parah mengamai pembengkakan berat (100\%). Hasil uji korelasi spearman nilai $\rho$ value = 0,1 yang bermakna bahwa ada Pengaruh antara stress pada ibu menyusui dengan pembengkakan payudara pada ibu menyusui di Desa Matanair Kecamatan Rubaru Kabupaten Sumenep

Dapat disimpulkan bahwa ibu yang megalami stress pada saat masa nifas (menyusui) akan berdampak pada terjadinya pembengkakakn payudara pada ibu. Oleh karena itu diperlukan banyak penegtahuan ibu menyusui tentang proses laktasi serta perubahan yang terjadi semasa ibu menyusi sebagai pencegahan akan rasa cemas dan kehawatiran ibu. Selain itu peran keluarga juga sangat penting dalam membantu dan mensupport ibu selama masa menyusui.
\end{abstract}

Kata Kunci : Stress, Meyusui, Pembengkakan Payudara.

\section{PENDAHULUAN}

Pembengkakan payudara dalam masa post partum merupakan kondisi dimana payudara membengkak yang disebabkan karena jumlah ASI yang berlebihan di dalam payudara. Biasanya hal ini disertai rasa nyeri. Pembengkakan payudara ini bisa terjadi di pada sebagian payudara atau seluruh payudara. Awalnya setiap ibu post partum menganggap kejadian pembengkakan payudara ini merupakan hal yang biasa dialami oleh ibu menyusui. Bahkan ada beberapa daerah di wilayah Sumenep yang menghubungkan kejadian pembengkakan payudara ini dengan "MITOS" budaya setempat. Pembengkakan 
payudara merupakan hal yang normal pada awal menyusui setelah persalinan. Dimana pada awal menyusui, bayi masih belum adekuat dalam meyusu, sehingga akan banyak sisa ASI dalam payudara menumpuk yang menyebabkan payudara membengkak. Walaupun kondisi ini normal diawal menyusui namun tidak menutup kemungkinan akan berlanjut pada komplikasi jika tidak ditangani dengan benar.

Ada bebebrapa faktor yang dapat menyebabkan terjadinya pembengkakan payudara, dan salah satunya adalah rasa cemas atau stress yang dirasakan oleh ibu post pastum. Ibu post partum sangat rentan sekali untuk mengalami stress selama masa nifas. Hal ini dikarenakan adanya perubahan hormonal secara cepat yang terjadi dalam tubuh ibu setelah proses persalinan. Rasa ketidaknyaman setelah masa persalinan dan trauma persalinan juga dapat mendukung terjadinya stress post partum. Stress post partum ini biasanya lebih sering terjadi pada ibu primi dibandingkan multi. Kondisi Psikologis ibu dapat merdampak terhadap produksi dan proses keluarnya ASI. Dimana untuk ibu yang mengalami stress post partum akan mengurangi proses mengeluaran ASI yang dapat menyebabkan terjadinya bendungan ASI. Dari masalah inilah, peneliti ingin melakukan penelitian tengtang Pengaruh Stres Post Partum Terhadap Pembengkakan Payudara pada Ibu Menyusui yang berada di Desa Matanair

\section{METODE PENELITIAN}

Penelitian ini termasuk dalam penelitian analitik dengan rancang bangun yang digunakan adalah cross sectional. Dengan menggunakan teknik Total Sampling, sampel dalam penelitian ini adalah semua ibu yang sedang menyusui di wilayah kerja Polindes Desa Matanair bulan Januari Februari 2019 yang berjumlah 18 orang. Variabel peneltiannya yaitu Stress dan Pembengkakan payudara.

Dalam proses pengumpulan data dalam penelitian ini menggunakan Kuesioner DASS 42 dan cheklistyang kemudian dianalisis menggunakan Uji korelasi Spearman dengan tingkat kemaknaanya adalah 0,05 .

Penelitian ini dilaksanakan di di

Wilayah kerja Polindes Desa

MatanairKecamatan Rubaru pada bulan

Februari Sampai April 2019.

\section{HASIL}

\section{DistribusiFrekuensi}

a. Stress pada ibu menyusui

Tabel 1. Distribusi frekuensi berdasarkan tingkat stress pada Ibu Menyusui di Desa Matanair Kecamatan Rubaru Kabupaten Sumenep

\begin{tabular}{cccc}
\hline \multirow{2}{*}{ No } & \multirow{2}{*}{ Stress } & \multicolumn{2}{c}{ Responden } \\
& & F & $\%$ \\
\hline 1 & Normal & 3 & 16 \\
2 & Ringan & 2 & 11 \\
3 & Sedang & 5 & 28 \\
4 & Parah & 7 & 39 \\
5 & Sangat parah & 1 & 6 \\
\hline & Jumlah & $\mathbf{1 8}$ & $\mathbf{1 0 0}$ \\
\hline
\end{tabular}

Tabel 1 di atas memperlihatkan bahwa dari 18 ibu menyusui di Desa Matanair Kecamatan Rubaru Kabupaten Sumenep pada bulan Januarai - februari 2019 hampir setengahnya responden memiliki tingkat stress yangparah yaitu sebanyak 7 (39\%) ibu menyusui.

b. Pembengkakan Payudara

Tabel 2. Distribusi frekuensi berdasarkan pembengkakan payudara pada Ibu Menyusui di Desa Matanair Kecamatan Rubaru Kabupaten Sumenep

\begin{tabular}{cccc}
\hline \multirow{2}{*}{ No } & Pembengkakan & \multicolumn{2}{c}{ Responden } \\
& Payudara & F & $\%$ \\
\hline 1 & Normal & 0 & 0 \\
2 & Ringan & 4 & 2 \\
3 & Sedang & 6 & 3 \\
4 & Berat & 8 & 5 \\
\hline & Jumlah & $\mathbf{1 8}$ & $\mathbf{1 0 0}$ \\
\hline
\end{tabular}

Tabel 2 di atas memperlihatkan bahwa dari 18 ibu menyusui di Desa Matanair Kecamatan Rubaru Kabupaten Sumenep pada bulan Januarai - februari 2019 hampir setengahnya responden mengalami pembengkakan payudara yang berat yaitu sebanyak 7 (45\%) ibu menyusui. 
2. Tabulasi silang antara stress pada ibu menyusui dengan pembengkakan payudara pada ibu menyusui

Tabel 3 Tabulasi silang antara stress pada ibu menyusui dengan pembengkakan payudara pada ibu menyusui di Desa Matanair Kecamatan Rubaru Kabupaten Sumenep

\begin{tabular}{lccccccccccc}
\hline & & \multicolumn{9}{c}{ Pembengkakan Payudara } & \multicolumn{3}{c}{ Total } \\
\cline { 3 - 8 } & No & Normal & $\%$ & Ringan & $\%$ & Sedang & $\%$ & Berat & $\%$ & $\sum$ & $\%$ \\
\hline \multirow{2}{*}{1} & Normal & 0 & 0 & 3 & 10 & 0 & 0 & 0 & 0 & 3 & 100 \\
2 & Ringan & 0 & 0 & 1 & 50 & 1 & 50 & 0 & 0 & 2 & 100 \\
3 & Sedang & 0 & 0 & 0 & 0 & 2 & 40 & 3 & 60 & 5 & 100 \\
4 & Parah & 0 & 0 & 0 & 0 & 3 & 43 & 4 & 57 & 7 & 100 \\
5 & Sangat parah & 0 & 0 & 0 & 0 & 0 & 0 & 1 & 10 & 1 & 100 \\
\hline & Jumlah & 0 & 0 & 4 & 22 & 6 & 33 & 8 & 45 & 18 & 100 \\
\hline
\end{tabular}

Tabel 3 di atas memperlihatkan bahwa dari 3 orang ibu yang tidak mengalami stress dalam masa nifas semuanya hanya mengalami pembengkakan payudara ringan saja $(100 \%)$. Dan dari 2 orang yang mengalami stress ringan pada masa nifas separuhnya mengalami pembengkakan payudra ringan $(50 \%)$ dan separuhnya lagi mengalami pembengkakan payudra sedang $(50 \%)$. Sedangkan ibu yang mengalami stress Parah sebagian besar menaglami pembengkakan payudara berat (57\%). Dan $1 \mathrm{ibu}$ yang mengalami stress berat selama masa nifas menaglami pembengkakan payudara berat $(100 \%)$.

Pada saat data ini dinalisis menggunakan uji korelasi spearman menghasilkan nilai $\rho$ value $=0,1$ yang bermakna bahwa tidak ada hubungan antara stress pada ibu menyusui dengan pembengkakan payudara pada ibu menyusui di Desa Matanair Kecamatan Rubaru Kabupaten Sumenep.

\section{PEMBAHASAN}

\section{Kejadian Stress}

Berdasarkan hasil penelitian yang telah dilakukan dari 18 ibu menyusui ditemukana bahwa hampir separuhnya ibu mengalami stress yang parah yaitu 7 orang (39\%), mengalami stress sedang sebanyak 5 orang (28 $\%)$, tidak mengalami stress sebanyak 3 orang (16\%), mengalami stress Ringan sebanyak 2 orang $(11 \%)$ dan yang mengalami stress sangat parah sebanyak 1 orang $(6 \%)$.

Hawari (dalam Yusuf 2004) menyatakan bahwa stres merupakan suatu respon tubuh terhadap permasalahn yang dialami dalam
kehidupannya.Hal ini sejalan dengan teori Richard (2010) yang menyatakan bahwa stres adalah proses penilaian terhadap suatu peristiwa yang dianggab mengancam atau berbahaya untuknya sehingga memunculkan suatu reaksi baik secara fisik, emosi, pengetahuan serta perilakunya.

Pada saat seseorang mulai mengalami kondisi yang mengarah pada stres, ada 2 aspek utama yang dapat mengalami dampak, yaitu : Fisik dan Psikologis. Pada fisik ibu akan merasakan adanya perubahan dalam kondisi tubuhnya seperti kembung, kenaikan asam lambung, diare dll. Sedangkan secara Psikologis akan ada perubahan emosi, perubahan tingkah laku, misalnya : ibu akan gampang sekali tersinggung, cepat marah, sangat sensitif, mudah menangis dan sedih.

Kondisi Stres inipun dapat terjadi pada masa post partum. Cukup banyak faktor yang dapat mendorong ibu post partum mengalami stres diantaranya :

a. Perubahan Fisik : Ibu post partum mengaalami banyak perubahan dalam tubuhnya mulai dari sistem hormon, perubahan Uterus, perubahan dalam alat genetalia, proses lochea, proses Laktasi, dll.

b. Rasa Nyeri yang dirasakan Ibu Post Partum : Nyeri Payudara (proses Laktasi)

c. Nyeri After Pain (proses Involusi), Nyeri Perinium, dll.

d. Lelah Mengurus Diri dan Bayinya

e. Kurangnya Istirahat

f. Kurangnya Nutrisi, dll 
Keadaan-keadaan diatas yang menyebakan besarnya resiko terjadinya stres pada ibu post patum. Apalagi jika dalam melakukan perawatan diri dan bayinya ibu post partum harus melakukan sendiri tanpa adanya bantuan dari suami atau keluarga. Keadaan ibu yang terlalu lelah juga dapat menyebabkan ibu post partum mengalami post partum.

\section{Kejadian Pembekakan Payudara}

Berdasarkan hasil penelitian yang telah dilakukan dari 18 ibu menyusui diperoleh data bahwa hampir separuhnya ibu mengalami pembengkakan payudara berat yaitu 8 orang (45\%), mengalami pembengkakan payudara sedang sebanyak 6 orang (33\%), dan mengalami pembengkakan payudara ringan sebanyak 4 orang (22\%).

Pembengkakan Payudara merupakan kondisi dimana payudara terasa oedem baik sebagian atau seluruh bagian payudara. Hal sering kali terjadi pada ibu menyusui terutama di awal-awal menyusui. Kondisi ini bisa terjadi dikarenakan pemberian ASI yang tidak adekuat dan terus menerus. Ibu biasanya menunggu bayi terbangun dan menangis untuk memberikan ASInya, selain itu pada saat memberikan ASInya ibu tidak pernah mengosongkan ASInya secara menyulur pada kedua payudara. Pada saat ASI tidak dikeluarkan secara menyeluruh disinilah dapat terjadi proses bendungan ASI di payudara. Jika bendungan ASI ini tidak dikeluarkan maka yang akan ibu rasakan adalah adanya rasa nyeri dan tegang pada payudara. Kondisi inilah yang terjadi pada ibu ibu menyusui di Desa Matanair Kecamatan Rubaru Kabupaten Sumenep.

\section{Hubungan Antara stress ibu Menyusui dengan pembengkakan payudara .}

Berdasarkan hasil penelitian dapat diketahui bahwa dari 3 orang ibu yang tidak mengalami stress dalam masa nifas semuanya hanya mengalami pembengkakan payudara ringan saja $(100 \%)$. Dan dari 2 orang yang mengalami stress ringan pada masa nifas separuhnya mengalami pembengkakan payudra ringan $(50 \%)$ dan separuhnya lagi mengalami pembengkakan payudra sedang (50 $\%)$. Sedangkan ibu yang mengalami stress
Parah sebagian besar menaglami pembengkakan payudara berat $(57 \%)$. Dan 1 ibu yang mengalami stress berat selama masa nifas menaglami pembengkakan payudara berat $(100 \%)$.

Pada saat data ini dinalisis menggunakan uji korelasi spearman menghasilkan nilai $\rho$ value $=\quad 0,1 \quad$ yang bermaknabahwaadapengaruhantarastress padaibumenyusuidenganpembengkakanpayuda rapadaibumenyusuidi

DesaMatanairKecamatanRubaruKabupatenSu menep

Pada dasarnya, keberhasilan proses menyusui dipengaruhi oleh 2 reflek, yaitu reflek prolaktin dan Let-Down Refleks. Reflek Proklatin adalah reflek yang muncul pada saat bayi menyusu, dimana hisapan bayi akan memberikan rangsangan pada puting dan daerah areolah. Rangsangan ini akan sampai pada Hypophyse Anterior melalui serabut afferent sehingga Hypophyse Anterior akan memproduksi hormon Prolaktin yang kemudian dialirkan ke dalam peredarahan darah untuk sampai ke kelenjar payudara. Hormon Prolaktin di dalam payudara memacu kelenjaralveoli untukmemproduksi ASI. Sedangkan Let-Down Refleks merupakan Reflek yang terjadi pada Saat hormon Oksitosin diproduksi oleh Hypophyse Posterior. Hormon ini bekerja untuk memacu otot polos kelenjaralveoli \& duktulus berkontraksi sehingga memeras ASI di kelenjar Alveoli, duktulus dan sinus menuju puting. Proses inilah yang menyebabkan ASI keluar. Pada saat ibu mengalami stres maka proses Let-Down Refleks inilah yang terganggu.

Penelitian ini sejalan dengan penelitian yang dilakukan oleh Rizki Amalia pada tahun 2016 di RSI A.Yani Surabaya tentang Hubungan antara Stres yang terjadi pada ibu menyusui pasca persalinan dengan Kelancaran ASI. Penelitian ini dilakukan pada 24 responden dan hasil penelitian menunjukkan adanya hubungan stres dengan Kelancaran ASI pada Ibu Menyusui Pasca Persalinan di RSI A.Yani Surabaya dengan angka Rho = 0,628. Psikologi ibu menyusui dapat mempengaruhi produksi dan pengeluaran ASI. Pada saat ibu khawatir dan berpikir produksi 
ASInya sedikit makan yang terjadi produksi ASI dalam payudara akan berkurang, dan sebaliknya pada saat seorang ibu hamil berfikir produksi ASInya melimpah makan produksi ASI dalam payudara akan bertambah. Hal ini terjadi karena pada saat ibu stres dan cemas maka akan ada penekanan terhadap produksi hormone Oksitosin sehingga akan menghambat proses pengeluaran ASI. Kondisi inilah yang menyebabkan bendungan ASI hingga pembengkakan pada payudara.

\section{KESIMPULAN DAN SARAN \\ Kesimpulan}

1. Hampir seluruhnya Ibu menyusui di Desa Mataair mengalami Stress yang parah.

2. Hampir seluruhnya Ibu menyusui di Desa Mataair mengalami Pembengkakan Payudara yang berat.

3. Ada Pengaruh stress ibu menyusi dengan terjadinya pembengkakan payudara di desa Matanair Kec. Rubaru Kabupaten Sumenep

\section{Saran}

Dengan adanya penelitian ini diharapkan peran tenaga kesehatan dalam memberikan informasi kepada ibu dan keluarga tentang proses laktasi serta perubahan yang terjadi semasa ibu menyusi sebagai pencegahan akan rasa cemas dan kehawatiran ibu. Selain itu peran keluarga juga sangat penting dalam membantu dan mensupport ibu selama masa menyusui.

\section{DAFTAR PUSTAKA}

Aini. (2009). Pembengkakan Payudara Ibu Post Seksio Sesarie Pada Masa Menyusui di Rumah Sakit Umum Daerah Ade Mohammas Djoen Sintang . Breast Swelling And Breastfeeding, 96.

Ambarwati, dkk. 2010. Asuhan Kebidanan Nifas. Yogyakarta : Nuha Medika.

Anggraini. 2010. Asuhan Kebidanan Masa Nifas. Yogyakarta: Pustaka Rihama

Astutik, Reni Yuli. 2014. Payudara dan Laktasi. Jakarta : Salemba medika

Bahiyatun. (2009). Pemberian Kompres Panas Terhadap Penurunan Nyeri Payudara Pada Asuhan Keperawatan Ny.Y dengan Post Partum Spontan di Ruang Mawar 1 Rumah Sakit Dr.Moewardi Surakarta. Surakarta: Prodi Studi DIII Keperawatan Sekolah Tinggi Ilmu Kesehatan Kusuma Husada.

Regina. (2011, Oktober 6). Gangguan Psikologi pada Masa Nifas . Diambil kembali dari Psikologi Masa Nifas: http://www.kebidanan.com

Suherni, dkk. 2009. Perawatan Masa Nifas. Yogyakarta

Veralls. (1997). Pembengkakan Payudara Ibu Post Seksio Sesarie Pada Masa Menyusui di Rumah Sakit Umum Daerah Ade Mohammas Djoen Sintang. Breast Swelling And Breastfeeding , 99

Waryono. (2010). Pembengkakan Payudara Ibu Post Seksio Sesarie Pada Masa Menyusui di Rumah Sakit Umum Daerah Ade Mohammas Djoen Sintang . Breast Swelling And Breastfeeding, 96. 